\title{
EVALUATIVE LANGUAGE IN BRITISH TOURIST DISCOURSE
}

\author{
Olena Tyschenko \\ PhD, Assistant Professor, Taras Shevchenko National University of Kyiv, Ukraine \\ e-mail: olenatyschenko2020@gmail.com, orcid.org/0000-0002-0759-7757
}

\author{
Martyna Krasucka \\ MA, Polonia University in Czestochowa, Interdisciplinary Faculty, Poland \\ e-mail: mkrasucka@ap.edu.pl,orcid.org/0000-0002-0648-6967
}

\section{Summary}

The aim of the article is to highlight pragmatic role of evaluative vocabulary in British travel articles. For this purpose, such notions as tourist discourse, evaluative language, pragmatic meaning are defined, main features of tourist discourse are described, pragmatic meaning of evaluative language in travel articles is identified. The research was conducted based on travel articles from the Official Tourism Website of Great Britain www.visitbritain.com. To carry out the research the following methods were used: descriptive, deductive methods as well as elements of functional, discourse, and pragmatic analysis.

Tourist discourse combines elements of several discourses, i.e. advertising, popular science and some specific ones. An essential feature of travel articles is the use of positive strategy, aimed at formation of positive attitude of potential tourists towards the tourist object. Such evaluative language means as evaluative attributive word combinations, evaluative adjectives, superlative adjectives, evaluative adverbs, connotatively marked nouns and verbs are used in British tourist articles to fulfill the pragmatic purpose, i.e. to positively impact the potential tourist.

Keywords: evaluative vocabulary, pragmatic meaning, travel articles, positive strategy, evaluation, linguistic means.

\section{DOI https://doi.org/10.23856/3915}

\section{Introduction}

Globalization processes have significantly influenced the development of tourism. Undoubtedly, it can be argued that English is the language of international tourism, thus, the English language investigation in tourist discourse is relevant in the framework of linguistics.

Nowadays scientists increasingly shift their focus to the peculiarities of tourist English. They explore its stylistic features, lexical and grammatical peculiarities as well as its social and cultural dimensions. The evaluative language in tourist discourse is also of interest for researchers. But the novelty of this investigation is due to the functional and pragmatic role of evaluative language in tourist discourse.

The purpose of the research is to define the role of evaluative language in British tourist discourse within the framework of its functional and pragmatic functions.

The purpose of the research constitutes accomplishment of the following objectives: to define the main notions of the research, i.e. of evaluative language and tourist discourse, to characterize the phenomenon of tourist discourse, to consider the evaluative language in terms of its role in organizing the whole text of a travel article, and to identify pragmatic meaning of evaluative language in tourist discourse.

Language data used in the research includes travel articles from the Official Tourism Website of Great Britain www.visitbritain.com. 
Research methods used for implementation of the tasks set out for the research include general scientific methods, i.e. descriptive and deductive methods as well as linguistic methods, i.e. elements of functional, discourse, and pragmatic analysis.

\section{Theoretical Framework of Tourist Discourse}

Tourism includes direct interaction between cultures, with special focus on communication and sharing between local and international cultures. Generally speaking, tourist discourse has the same objectives as the advertising discourse: to capture attention, to maintain interest, to create desire, and finally to get action. In order to fulfill these functions, specific advertising techniques are used to shape consumer behavior (Teodorescu, 2014: 367). Tourist texts are expected to play a persuasive role in order to attract tourists (Younesi, 2018: 40). Tourist discourse is the text implemented in institutional situations of communication in the subject area of tourism. Tourist discourse is a special subspecies of advertising discourse (Ivanova, 2017: 105).

According to L. M. Goncharova, speech impact in travel advertising is carried out in such a way as to convince a potential client of high quality, uniqueness, safety of the service provided. In addition, by advertising a travel product, the advertiser affects the consciousness, intelligence of the consumer, attracting his/her background knowledge, awakening the desire to comprehend new things, stimulating interest and arousing curiosity (Goncharova, 2011: 202-203).

Based on the information mentioned above, it is obvious that tourist discourse contains many features of advertising discourse. But, on the other hand, it also has features of popular science discourse. According to the researchers, popular science discourse comprises a set of texts relevant to one area of communication, taking into account extralinguistic factors, addressing-targeting interaction, communicative attitude (Bezsonova, 2016: 107); popular science discourse in modern conditions is united by a thematic community and by the purpose of communication, i.e. the desire to influence society, prepare it for adequate social interaction and the solution of interdisciplinary global problems. In other words, popular science discourse becomes the central unit of speech activity, the main characteristics of which are the conscious active participation of communicants in a socially significant action that has an initially dialogical nature; this action is due to extralinguistic factors, caused by the whole set of circumstances in which the life of the communicants proceeds, including their personal experience, the norms of society and the dominants of culture (Egorova, 2009: 44). So, it is possible to state that tourist discourse combines the features of advertising and popular science discourse.

Tourist discourse is a complex discursive formation. Its communicative space includes interdependence, interaction of tourism, advertising tourism, scientific, business, didactic, legal (legislative) subspecies of tourist discourse. Within each subspecies of tourist discourse you can find inclusions of historical, art history, journalistic, culinary and other discourses. In this case, we are talking about hybridization of tourist discourse (Kosickaya, 2014: 192).

As an independent type of discourse, tourist discourse is distinguished on the basis of a special thematic focus (travel and recreation), orientation towards a strictly defined addressee (tourist), uniqueness of the goal (inform the addressee about a trip), as well as due to the existence of institutions (tour operators, international organizations), special tourism ethics, well-developed and extensive tourism terminology. Tourist discourse is a special mass information and status-oriented institutional discourse (Kosickaya, 2014: 192).

According to N.V.Filatova, tourist discourse is characterized by the following parameters:

1) participants: seller (tour operator) - client; tour guide - excursionist; compiler of the text - the recipient of the text; 
2) place: office, tourist bus, museum, city street, virtual space, text space;

3) goals: making a profit - receiving excursion and tourist services;

4) key concept: travel;

5) strategies: the positive strategy;

6) material: a large set of topics, including regional and historical information, tour organization, hotel business, transport, security, food, etc.;

7) varieties and genres: depending on the channel transmission of information there are oral and written varieties of tourist discourse; the written variety includes printed texts and computer-mediated communication, oral variety is divided into direct and indirect (Filatova, 2012: 78).

If we consider tourist discourse strategies, the most defining for our research is the positive strategy proposed by L. M. Goncharova. The researcher states that while reading tourist magazines, the potential client is immersed in the world of long-distance travel dreams, luxury hotels, fabulous life in exotic countries. Only in this area of professional speech communication, we will never meet anything evil, vulgar, scary or repulsive. Here the reader finds only fascinating information about different cities and countries, mesmerizing promises and offers of travel agencies. Such a positive strategy is obvious and justified, because no one wants to pay a lot of money for their own stress. Speaking of advertising in the tourism sector, it is important to remember that the use of verbal means is aimed at making the addressee feel a positive attitude (Goncharova, 2011: 203).

So, tourist discourse mainly combines features of advertising and popular science discourses, but it also comprises the elements of special for each communicative act type of discourse, e.g. culinary, historical, journalistic etc. Tourist discourse has its own varieties with their own discourse strategies.

\section{Evaluative Language}

According to Cambridge Dictionary, evaluation is the process of judging or calculating the quality, importance, amount, or value of something (Cambridge Dictionary). Merriam-Webster Dictionary also gives the definition of evaluation as determination of the value, nature, character, or quality of something or someone (Merriam-Webster Dictionary).

Evaluative language can be described as a positive or negative language which judges something's worth. It involves language for expressing feelings and thoughts, evaluating aspects of people like their behavior, and assessing the nature of objects like literary works.

Evaluation may be defined as semantic-stylistic category, which, based on the opposition of partial values of negative, positive or neutral assessment, conveys the attitude of the speaker to the named subject, phenomenon, concept. In terms of content, the assessment can be neutral, positive and negative, and in terms of expression it can be explicit and implicit. Explicit units transmit the assessment directly, and implicit ones need more complex and deeper indirect process of perception (Kots, 2016: 79).

Evaluation may be regarded as a component of pragmatic meaning of the word, expressing the attitude of the subject of evaluation to the object of extra-linguistic reality by correlating its individual signs with a system of values adopted in a given language community. Evaluation highlights a certain feature of an object, event, fact, phenomenon, it is an anthropocentric phenomenon and helps a person to orient in historical time and space (Lyzlov, 2009: 7).

Evaluation as a linguistic category is based in its semantics on axiological constant, formally expressed by different languages means - morphological, lexical and syntactic, generalized invariant value of approval / disapproval of actions, processes, phenomena, facts etc. (Chmel, 2016). 
The concept of evaluation is inextricably linked with the expression of emotional human attitude to the object of expression. Giving an assessment, the speaker expresses his positive or negative attitude on any grounds. In structure of the meaning of the word evaluation is associated primarily with emotional component of connotation, which includes both rational and emotional evaluation. Much of the evaluative vocabulary is potentially connected with emotional component. That is, everything that surrounds a person causes him an evaluative reaction. At the syntactic level, there are connotations that reflect the relationship between language units and existing non-linguistic object, phenomenon and user. Connotative information is a product of speech process and arises as a result of activation of the expressive potential of expressive-syntactic constructions. It increases the impact on the person and causes him/her emotional and evaluative attitude to a particular object, event or condition (Chmel, 2016).

\section{Pragmatic Meaning of Evaluative Language in Tourist Travel Articles}

As it was mentioned above, there are different varieties of tourist discourse which can be related to its genres. Researchers distinguish three subtypes of tourist discourse, each of which has a specific lexical composition, genre and stylistic features, specific communication strategies and tactics: professional (serves the business process in the tourism industry), academic (operates in the training of tourism professionals, as well as scientific analysis of practical activities in this sector of the economy) and public (aimed mainly at disseminating information about the tourism industry and attracting customers) (Tarnaeva, 2013).

N.V. Filatova speaks about the following genres of tourist discourse: excursion (including communication between the excursionist and the guide), dialogue with the seller of the service (dialogue between the representative of the travel agency and the client in the office or outside the office), dialogue with the representative of the receiving party (between the client / accompanying group and the hotel employee / driver of the tour bus), dialogue between the tour operator and the contractor (booking hotels, air tickets, etc.), on the periphery of the genre field - speech interaction in special circumstances (negotiations with the consulate) (oral type of direct communication); video guide - geographic overview documentary, audio guide (oral type of mediated communication); guidebook, tourist brochure, catalog, article, brochure, leaflet (written variety in the form of printed texts); virtual tour, tourist office website, customer email to tourist office, tourism employee email (computer-mediated writing variety) (Filatova, 2012: 79).

In our research we relate travel articles to the public subtype of tourist discourse. The aim of public tourist discourse is to form a potential tourist's positive attitude to the proposed tourist product and further implementation of this product, so this subtype of tourist discourse uses mainly manipulative strategies that involve influencing the recipient to encourage post-communicative actions. desirable for the other side of communication (Tarnaeva, 2013).

Pragmatics as a science studies linguistic units in their use, in attitude towards

those who use them. Pragmatic meaning is the meaning that a word acquires in a speech situation (Labzina, 2012: 131). Any evaluative vocabulary is a pragmatic oriented vocabulary, because it characterizes the speaker's attitude, his assessment and is connected with his personality, his subjective values and preferences (Bohieva, 2017). One can distinguish between positive, negative and neutral evaluative statements (Boboshko, 2012).

Having conducted the research, it is possible to state that evaluative language in British travel articles includes the following linguistic means: evaluative adjectives, superlative adjectives, evaluative adverbs, connotatively marked nouns and verbs, as well as evaluative attributive word combinations. 
The most evident elements of the evaluative language used in British travel articles are evaluative adjectives. While analyzing the article Dream-worthy walks along the England Coast Path (VisitBritain, 2020), such evaluative adjectives have been found: striking, quaint, tranquil, incredible, spectacular, breathtaking, delicious, imposing, beautiful, picturesque, outstanding, exciting, picture-perfect, delectable, stunning, exceptional, instagrammable etc. Let's take a look at their usage in more detail.

The first sentence of the article contains several evaluative adjectives: From striking cliffs rising out of the sea to sandy coves and quaint fishing villages, England's coastline offers a tranquil escape if you're dreaming of the great outdoors. We read further: Passing some of England's most tranquil spots, you will be able to take in breathtaking scenery en route, explore historic castles, tuck into delicious fish and chips and find fossils in ancient cliffs - these are just some of the top things along England's Coast Path that helped England take second spot in the Lonely Planet's Best in Travel 2020. So, the first two paragraphs of the article are written in such a way to create a positive atmosphere and positive perception by the readers.

The positive communicative strategy mentioned above is also obvious due to the usage of superlative adjectives, e.g. England's most tranquil spots, and evaluative adverbs, e.g. Daydreamers can imagine taking in the breathtaking views from the imposing walls of Bamburgh Castle that stand proudly overlooking this Area of Outstanding Natural Beauty.

The evaluative language is also expressed by the use of connotatively marked nouns, e.g. abundance (A designated stretch of historic coastline, Durham's wild cliffs and sweeping dunes are home to an abundance of wildflowers, insects and other wildlife), magnificence (A designated Area of Outstanding Natural Beauty for over 50 years, the Norfolk Coast contains everything from the sweeping sand dunes and salt marshes of Holkham National Nature Reserve to the magnificence of Holkham Hall stately home,) and connotatively marked verbs, e.g. to teem (With its imposing castles and offshore islands that are teeming with wildlife, the Northumberland coast offers beauty and history in equal measure), to savour (Foodies can savour the prospect of sampling delectable cuisine from top chefs in Whitstable, while animal fans can look forward to spotting wild birds around Romney Marsh and the bird reserve at Dungeness), to dream, to spark (If you're a fan of Britain's rich ancient history and folklore you can dream of uncovering the area's connection to the legend of King Arthur and a coastline that has sparked the imagination for centuries).

Noticeable is the usage of evaluative attributive word combinations: striking cliffs, sandy coves, quaint fishing villages, a tranquil escape, great outdoors, incredible beauty spots, spectacular places, breathtaking scenery, historic castles, delicious fish and chips, ancient cliffs, imposing castles, breathtaking views, imposing walls, wild cliffs, sweeping dunes. Such attributive word combinations arouse readers' positive feelings, implementing positive strategy.

\section{Conclusions}

So, tourist discourse is hybrid formation which includes elements of some other discourses with its own genres and communicative strategies. Characteristic of travel articles is the use of positive strategy, which is aimed at creation of potential tourists' positive attitude to the tourist object. The whole structure of travel articles as well as their linguistic means serve the purpose of getting a positive message across to potential tourists.

The use of evaluative language is typical of travel articles, it is pragmatic oriented, and the evaluation is always positive. Evaluative linguistic means used in British tourist articles include evaluative attributive word combinations, evaluative adjectives, superlative adjectives, evaluative adverbs, connotatively marked nouns and verbs. Comparison of evaluative language in other genres of tourist discourse is of interest for further research. 


\section{References}

Bezsonova A.S. (2016) Ponyatie "nauchno-populyarnyj diskurs" v lingvisticheskoj literature [The concept of "popular science discourse" in linguistic literature]. Skhidnoslovianska filolohiia. Movoznavstvo, 29. 109-115.

Boboshko T. M. (2012) Komunikatyvno-prahmatychnyi kharakter katehorii otsinky [Communicative and pragmatic nature of the category of evaluation]. Mova i kultura, 15 (1). 105-112.

Bohieva M.V., Stepanova I.Zh. (2017) Pragmaticheskie funkcii leksicheskih edinic v hudozhestvennom tekste [Pragmatic functions of lexical units in literary text]. Mir lingvistiki i kommunikacii: elektronnyj nauchnyj zhurnal, 4. 67-77.

Chmel V.V., Akhmad I.M. (2016) Vyrazhennia katehorii otsinky na leksychnomu ta syntaksychnomu rivniakh $v$ anhliiskii ta ukrainskii movakh [Expression of the evaluation category on lexical and syntactic levels in English and Ukrainian]. Naukovyi visnyk Khersonskoho derzhavnoho universytetu. Seriia «Linhvistyka»: Zbirnyk naukovykh prats, 26. 168.

Dream-worthy walks along the England Coast Path (2020) VisitBritain: The Official Tourism Website of Great Britain. Retrieved from https://www.visitbritain.com/gb/en/dream-worthywalks-along-englands-coastpath

Egorova L.A. (2009) K voprosu ob opredelenii ponyatiya «Nauchno-populyarnyj diskurs» [On the question of defining the concept "Scientific popular discourse"]. Rusistika, 1. 42-46. Evaluation. (n.d.). In Cambridge dictionary. Retrieved from https://dictionary.cambridge.org/dictionary/english/evaluation

Evaluation. (n.d.). In Merriam-Webster.com dictionary. Retrieved from

https://www.merriam-webster.com/dictionary/evaluation

Filatova N.V. (2012) Zhanrovoe prostranstvo turisticheskogo diskursa [Genre space of tourist discourse] Rema, 2. 76-82.

Goncharova L.M. (2011) Strategii i taktiki reklamnyh tekstov turistskoj sfery

[Strategies and tactics of advertising texts for the tourism sector]. Servis v Rossii I za rubezhom, 7 (26). 202-209.

Ivanova I.M. (2017) Linhvistychni i sotsiokulturni osoblyvosti tekstiv anhlomovnykh ohliadovykh ekskursii [Linguistic and sociocultural features of the texts of English-speaking sightseeing tours]. Visnyk Kyivskoho natsionalnoho linhvistychnoho universytetu. Seriia : Pedahohika ta psykholohiia, 26. 103-112. doi: https://doi.org/10.32589/2412-9283.26.2017.135401 Kosickaya F.L. (2013) Zhanrovaya palitra francuzskogo turisticheskogo diskursa [The genre palette of French tourist discourse]. Vestnik Tomskogo gosudarstvennogo pedagogicheskogo universiteta 3 (131), 192-195.

Kots T. (2016) Otsinnist yak semantyko-stylistychna katehoriia publitsystychnoho styliu [Evaluation as a semantic and stylistic category of journalistic style]. Ukrainska mova, 4. 78-86.

Labzina P.G. (2012) Ocenka kak osnovnaya kategoriya pragmatiki [Evaluation as the main category of pragmatics]. Almanah sovremennoj nauki i obrazovaniya, 11 (66). 130-132.

Lyzlov A. I. (2009) Ocenka i yazykovye sposoby ee vyrazheniya v paremiyah

[Evaluation and linguistic ways of expressing it in proverbs]. [Doctoral dissertation, Moscow Region State University].

Tarnaeva L.P., Dacyuk V.V. (2013) Turisticheskij diskurs: lingvopragmaticheskie harakteristiki [Tourist discourse: linguopragmatic characteristics]. Vestnik SPbGU, 9 (13). 229-235.

Teodorescu A. (2014) Tourism Discourse - A linguistic analysis of tourism

websites. Language and Literature - European Landmarks of Identity, 15, 367-372.

Younesi A., Navidinia H., Ozhan A.R. (2018) Tourism discourse analysis: Comparing the vocabulary features used in the original and translation of Iranian tourism texts. e-Review of Tourism Research, 1(15), 37-51. 